\title{
Corruption Eradication in Indonesia during the Covid-19 Pandemic: An Analysis of the Implementation of Article 27 Law Number 2 of 2020 Concerning State Financial Policy and Financial System Stability for Handling Covid-19 Pandemic
}

\author{
Jamin Ginting ${ }^{1, *}$ and Chelsya Gabriella ${ }^{2}$ \\ ${ }^{1}$ Lecturer at Faculty of Law, Pelita Harapan University, Tangerang, Indonesia \\ ${ }^{2}$ Alumni at Faculty of Law, Pelita Harapan University, Tangerang, Indonesia
}

\begin{abstract}
As Indonesia announced its first Covid-19 case on 2 March 2020, the government issued Acts Number 2 Year 2020. Article 27.1 and 27.2 of the Act do not provide legal certainty because they may release the state-officialcorruptors from their criminal responsibility. Through this paper, the author argues the criminal-responsibility exception by elaborating the ideas of the 1945 Constitution and the Corruption Act.

The author uses normative legal research to construct the paper by bringing the 1945 Constitution, Indonesian Penal Code, and Government Administration Act as contra-materials toward Acts Number 2 Year 2020. The author also uses the theories from Indonesian Law Scholars to base the author's argument.

The paper provides the construction of criminal corruption as one of the essential parts of state loss. It also explains the solution to remove the criminal-responsibility-exception by using the excellent faith principle.

The paper would return the good faith principle into the implementation of Act Number 2 Year 2020.

As Act Number 2 Year 2020 is considerably new on implementation, this paper provides new insight into the better implementation of corruption-handling during the Covid-19 Pandemic.
\end{abstract}

Keywords: Corruption, good faith, legal certainty, covid-19, Indonesian Law, government crimes, pandemic.

\section{INTRODUCTION}

Indonesia is a state of law (rechstaat) as stated in Article 1.3 of the 1945 Constitution of The Republic of Indonesia (called the 1945 Constitution). It explains that the law stands for the truth and will permanently eradicate rottenness, badness, depravity, dishonesty, and deviation. Besides Indonesia as reschtsaat, Indonesia also holds the principle of the rule of law, equality before the law, and respect for human rights. The 1945 constitution explains that the rule of law is not only based on vague law and formalistic law. The ideal law is not the law set solely based on absolute power or absolute authority. This specific law is not compatible with the 5th principle of Indonesian-FivePrinciples (Pancasila).

The state-of-law country mandates that every attitude and action of the government and the society must be based on and can be accounted for before the law, including the implementation of national development, also must be based on law. Recognition and protection of the state of law's concept that realized in society, nation and state are regulated by the law for equality (equality before the law).

*Address correspondence to this author at the Lecturer at Faculty of Law, Pelita Harapan University, Tangerang, Indonesia;

E-mail: jamin.ginting@uph.edu
In order to cope with Covid-19, the House of Representatives issued Acts Number 2 Year 2020 on 12 May 2020. Article 27 of the law creates polemic as the following contents:

1) Costs set by the Government and/or The Financial System Stability Committee (in Bahasa Indonesia KSSK) in the context of implementing the state revenue policy, such as the policies of taxation; state expenditure; regional expenditure; and state economic recovery program, are part of the costs to save the economy from the crisis and are not considered as a loss to the state.

2) Members KSSK, Secretary KSSK, Secretariat's Members KSSK, and officials or employees of the Ministry of Finance; Bank of Indonesia; the Financial Services Authority; the Deposit Insurance Corporation; and other officials related to the implementation of the Acts cannot be sued both in civil law and criminal law if in carrying out duties based on good faith and following with the provisions of laws and regulations.

Article 27.2 of the Acts has a legal loophole, and it gives legal immunity to state officials as the phrase says, "cannot be prosecuted both civil and criminal." Article 27.1 of the 1945 Constitution states that all 
citizens are equal before the law, and the government is obliged to uphold the law without exception. The legal immunity as meant in Article 27.2 of the Acts is also contradicted with the explanation of Article 2 of Acts Number 31 Year 1999 (the Corruption Acts). The corruption acts may aggravate the sentence with the death penalty if the criminal acts are committed in a specific condition.

Based on the background above, the problem formulation of this paper would be:

1. How does the state loss, as meant in Article 27.1 of Acts Number 2 Year 2020, provide legal certainty during the Covid-19 pandemic?

2. What is the state official's action under the provisions of article 27.2 of Acts Number 2 Year 2020 that the action cannot be accounted for criminal responsibility, as it is related to the existence of good faith in the corruption acts during the Covid-19 pandemic?

\section{DISCUSSION}

\section{State Losses in Article 27.1 Acts Number 2 Year 2020 In Providing Legal Certainty During the Covid- 19 Pandemic}

The policies of Acts Number 2 Year 2020 are providing tax incentives, reducing the corporate income tax rate, extending the tax application/settlement's deadline, granting customs facilities, taxing electronic transactions, and extending the personal annual tax's deadline. The financing policies, which consist of 5 (five) steps, are optimization of non-debt financing sources, cash loan flexibility, flexibility in adding State Notes (Surat Berharga Negara), and prioritizing State Notes' issuance through the market and retail mechanisms, and support the Bank Indonesia. Besides, the budget allocation in the National Economic Recovery program is Rp. $695,200,000,000,000$ (six hundred and ninety-five trillion two hundred billion rupiahs). In the implementation, the government has set 3 (three) policies that increase domestic consumption, increase business activity, and maintain economic stability \& monetary expansion.

However, there is a rule that provides legal loopholes. Article 27.1 of Acts Number 2 Year 2020 states: "Costs that have been incurred by the Government and/or The Financial System Stability Committee member, in the context of implementing state revenue policies include policies in the field of taxation; state expenditure policies including policies in the regional finance sector; financing policies; financial system stability policies and national economy's recovery programs, is part of the economic costs to save the economy from the crisis and not a loss to the state."

The regulations about "states losses" can only be found in article 2 and article 3 of the Corruption Act from many types of corruption. The rest of the Corruption Act does not require "state loss." For example, for an official who accepts a bribe from someone, this action cannot be determined as a state loss. The norms in Article 2.1 of the Corruption Act are different from the phrase that states loss is changed into the economic cost. Article 27.2 implies that the state finances/assets' reduction is not always the result of acts against the law. Likewise, an act detrimental to state finances is not always recognized as a criminal act of corruption. In addition, it implies that as long as the costs incurred by the Government and/or member of The Financial System Stability Committee institutions in the framework of implementing policies in the field of taxation, state expenditure policies, including policies in the regional finance sector, financing policies, financial system stability policies, and national economic recovery programs, based on the provisions of the prevailing laws and regulations, the costs cannot be classified as state losses and an element of the criminal act of corruption.

On the other hand, when the costs of implementing these various policies are carried out against the law, then both the Corruption Act and the State Treasury Law apply to ensnare the act. Based on Constitutional Court Decision Number 23/PUU-XIV/2016 regarding Review of Acts Number 31 of 1999, an actual calculation or actual loss is needed by the competent institution. Only then the element of detrimental to state finances will be proven.

The change of phrase from "state losses" to "economic costs" in Article 27.1 Acts Number 2 Year 2020, the implementation of law enforcement will undoubtedly be unclear. Given that all decisions and policies during the Covid-19 period were carried out under certain circumstances that could potentially lead to corruption. Changing the meaning of state loss into an economic cost will undoubtedly create legal uncertainty in its implementation, especially in the criminal act of corruption. 
According to Van Apeldoorn's opinion, legal certainty has two aspects: the law can be determined in concrete terms and legal security. The justice seekers want to know the constitution before starting a case and protection for society. Without legal certainty, a person will never know what to do. This will create uncertainty which leads to violence/chaos due to the indecisiveness of the legal system. Legal certainty's purpose is a clear and consistent law implementation that is not affected by subjective circumstances.

Article 27.1 of Acts Number 2 Year 2020 is also contradicting with Article 5.f Acts Number 12 Year 2011 concerning the Formation of Prevailing Laws, which states forming the Prevailing Laws must be carried out based on the principle of the formation of good Prevailing Laws, one of them is the clarity of formulation. The clarity of formulation means that each regulation must meet the technical requirements for drafting, systematics, choice of words or terms, legal language that is straightforward and easy to understand, then the law would not cause multiinterpretations in its implementation.

Article 28D.1 of the 1945 Constitution states, "Every person shall have the rights of recognition, guarantees, protection, and fair legal certainty, and equal treatment before the law." This is also emphasized by Frej Klem Thomsons, saying that the principle of equality before the law is a principle of procedural legal equality will hold that a court ought to treat a case in a certain way if similar cases have been treated that way before. Wallerstein also states that the fundamental social equality of all individuals is endowed with equal rights. Article 28D.1 of the 1945 Constitution could be interpreted as that the law must apply to everyone in the same way and method.

Exceptions about all expenses incurred by the Government cannot be categorized as "state losses" instead "economic costs," which potentially eliminate one of the essential elements in the criminal act of corruption as regulated in Article 2 and Article 3 of the Corruption Act. The phrase "not a state loss" in Acts Number 2 Year 2020 is inappropriate considering that the focus is only on the economy and not related to the Covid-19 handling. Besides, the shifting from "state loss" to "economic costs" makes corruption's legal enforcement grey. This exception is also contradictive with the explanation of Article 2 of the Corruption Act, which aggravates the sentence to the death penalty if the corruption act is committed in a particular condition such as the Covid-19 pandemic.
The State Official's Action under the Provisions of Article 27.2 of Acts Number 2 Year 2020 which Cannot Be Accounted for Criminal Responsibility Related with The Existence of Good Faith in The Corruption Acts during Covid-19 Pandemic

Article 50 of the Indonesian Penal Code (the Penal Code) states that "Whoever commits an act to implement the provisions of the law, is not a criminal." $R$. Soesilo explained that implementing the law is limited to carrying out actions ordered by law and including actions that are carried out on the authority granted by the law. If a policy taken is an act of implementing a law. As long as it does not exceed its authority, then the policy cannot be penalized. Therefore, Article 50 of the Penal Code means that an official has a justification for committing an act that can be punished if it has not based on the law's order.

Based on the theory of responsibility, the monistic theory, and the dualistic theory, a criminal is not punished with the existence of a justification because the act that is against the law is justified. While based on dualistic theory, the nature of being against the law and the justifying reasons are elements of a criminal act which does not depend on the formulation of a criminal act. The existence of justification reasons makes the criminal act not proven, so the criminal is released. Therefore, Article 27.2 of Acts Number 2 Year 2020 is not a justification for eliminating criminal responsibility in the perpetrator. Based on Article 27.2 of Acts Number 2 Year 2020, the act requires good faith in implementing the laws and regulations.

According to Article 27 paragraph 2 requires that with good faith, The Financial System Stability Committee (KSSK) members, The Financial System Stability Committee (KSSK) secretaries, members of the Financial System Stability Committee secretariat, and officials or employees of the Ministry of Finance, Bank Indonesia, the Financial Services Authority, the Deposit Insurance Corporation, and other officials cannot be prosecuted both civil and criminal if carry out the task with good faith and by the provisions of laws and regulations.

Acts Number 2 Year 2020 does not define the meaning of good faith itself. However, the Black's Law Dictionary defines good faith as a state of mind that is honest thought in belief or purpose, loyalty to duty or obligation, proper adherence to trade or business, and no intention to cheat or profit. An Edward Bayley states, "good faith is a vague concept. It is not clear 
whether good faith requires honest conduct, cooperative conduct, reasonable conduct, or a combination thereof. In the United States, the obligation to act in good faith in The Uniform Commercial Code is also not very broadly defined. The judges there also did not provide a clear definition when they based their decisions on good faith. Robert $S$. Summers argues that good faith is an "excluder" because judges usually use the term good faith to rule out particular behaviours.

To evaluate good faith, evaluation can be relative/subjective or absolute/objective. Relative evaluation is carried out by looking at actual behaviour, and it could be seen as good faith. The final evaluation determines that the condition is acceptable and does not conflict with the general environment. At the same time, Criminal Law rarely uses the term of good faith and more often uses the term of on purpose, knowing that, knowing about, with intent.

Based on Acts Number 2 in the Year 2020, corruption can be categorized as administrative corruption because the potential for corruption can be carried out during the implementation of policies or decisions. Administrative corruption is not mentioned in the Corruption Act, but it can be equated with Article 3 of the Corruption Law. It states that any person who benefits himself or another person or a corporation misuses the authority, opportunity, or means available to him because of his position or position that can harm the state finances or the state economy.

The establishment of Acts Number 2 Year 2020 provides legal certainty for the government in establishing specific policies and steps in handling health and economic emergencies caused by Covid19. One of the legal certainties referred to is Article 27.2 of Acts Number 2 Year 2020, where the article is intended for the government to have discretion in handling Covid-19. The discretion itself must be based on good faith. In order to determine good faith, Article 24 of the Government Administration Law regulates the objectives and conditions for the use of discretion.

The implementation of Article 27.2, Acts Number 2 Year 2020 must be connected with other laws such as the 1945 Constitution, same-level Acts, and Ministerial regulations. Without explicit parameters of good faith in Article 27 paragraph (2), the author also believes that a parameter is needed to determine good faith, further regulated in the Act. Based on the problem formulation of this paper, the Government Administration Act and the Limited Company Act can be used as one of the parameters to determine the existence of good faith in Article 27.2 of Acts Number 2 Year 2020.

First, in the Government Administration Act, the determination to measure the good faith of a person can be assessed with general principles of good governance. General principles of good governance are principles used as a reference for the use of authority for Government Officials in issuing Decisions and/or Actions in government administration. They are part of a general legal principle and are essential in every government's legal action. The general principles of good governance are contained in Article 10 of the Government Administration Act, which is legal certainty, expediency, impartiality, accuracy, not abuse the authority, openness, public interest, good service, and other general principles which judges use as the basis for judgments in the court decisions.

According to the explanation of Article $24 \mathrm{~F}$ of the Government Administration Act, good faith is a decision and/or action that is determined and/or carried out based on the motive of honesty and based on the general principles of good governance. Seeing general principles of good governance become one of the bases used to determine good faith. The authors believe that the principles can be used as a reference to implement Acts Number 2 Year 2020. Article 22.2 of the Government Administration states that one of the objectives of the principles is to overcome government stagnation in certain circumstances for the benefit and public interest. Government stagnation is the inability to carry out government activities due to a disaster or political turmoil. Therefore, if a government official related to Acts Number 2 Year 2020 violates these rules, he can still be prosecuted, both civil and criminal.

Second, the parameters of good faith in the Limited Company Acts, the board of directors' responsibility in managing the company must be based on good faith and prudence and by the laws/the company's Articles of Association. Therefore, if the Board of Directors has carried out its duties based on the principle of fiduciary duty, it cannot be held personally accountable. However, if a Board of Directors in carrying out management has violated the principle of fiduciary duty, then the Board of Directors must be held accountable for its actions. To be freed from personal responsibility, the Board of Directors must prove its actions under the criteria in Article 97.5 of the Limited Company Act, which in this article is said to be a form of the embodiment of the business judgment rule doctrine. 
They were referred to corruption cases by the former President Director of PT. Pertamina, the author, thinks that Karen Agustiawan's release has met the requirements of Article 97.2 of the Limited Company Act, which is carried out in good faith and full of responsibility. By carrying out the management in good faith, Karen Agustiawan's act of making an investment that caused state loss is not criminal. The process for assessing the presence of good faith is through the court. If, in court, a Board of Directors is proven to have committed a violation, then the juridical consequence is that the Board of Directors must be held accountable for its actions. Looking at Karen Agustiawan's case, it must be proven that losses arising from the investment result from a business decision, and there is no ill will in making that investment decision. Evidence of the presence or absence of good faith in Karen Agustiawan's case is also seen in the investment preparation process. It can be seen that in the investment process, Karen Agustiawan has carried out the management in good faith by fulfilling the required documents and referring to the Regulation of State Minister for State-Owned Enterprises Number: PER-09 / MBU / 2012.

In Karen Agustiawan, the good faith he did as President Director was that there were no elements of fraud, conflict of interest, illegal acts, and deliberate mistakes. Apart from that, the loss suffered by PT. Pertamina is also a decrease in value and is not the result of an illegal act, so that the author agrees with the Panel of Judges on Cassation, which states that Karen Agustiawan's actions are not a crime.

Based on the explanation above, establishing good faith in Article 27.2 of Acts Number 2, Year 2020 can be assessed in two ways: the act is carried out in good faith, and the act is following the provisions of laws and regulations. First, the assessment of good faith can be judged that there is terrible intention (men's rea) in his actions within the act. Moeljatno explained that in the dualistic theory, the conditions for imposing a criminal offense include acts against the law (actus reus) and elements of wrongdoing (mens rea). If actus reus has been fulfilled, then the prosecution can be carried out. In the prosecution phase, the public prosecutor can proceed to the trial stage to provide evidence related to mens rea as to the basis for the judgment by the judge. According to Andi Hamzah, there are no mistakes without being against the law, but there may be an act against the law without the mistakes.

In terms of punishment, Article 10 of the Penal Code regulates the types of sentences that are principal and additional sentences. The principal sentence consists of the death penalty, imprisonment, confinement, fines, and criminal closure. Meanwhile, an additional sentence consists of revoking certain rights, confiscating certain items, and announcing a judge's decision. In the Corruption Act, the types of sanctions that can be imposed on the accused of a criminal act of corruption are the death penalty, imprisonment, additional punishment, and for crimes committed by or on behalf of a corporation, the main punishment that can be imposed is a fine with a maximum provision of $1 / 3$. During the Covid-19 pandemic, the application of the death penalty for corruptors is regulated in Article 2.2 of the Corruption Act. However, applying the death penalty is followed by the condition that corruption is carried out in "certain circumstances."

An explanation of Article 2.2 of the Corruption Act, the "certain circumstances" provision intends to aggravate the perpetrators of corruption if the crime was committed during a state of danger, in the event of a national disaster, or a state of economic and monetary crisis. Article 2.2 of the Corruption Act regulates that a corruptor can be convicted with the death penalty, which has never been applied. The corruptor does not fulfil certain conditions if the criminal act is committed against funds intended for disaster.

\section{Disaster Management in Indonesia with The Acts Number 24 Year 2007}

Article 1.1 of Acts Number 24 Year 2007 states that a disaster is an event or series of events that threatens and disrupts people's lives and livelihoods caused, either by natural factors and/or non-natural factors as well as human factors, resulting in the incidence of human casualties, environmental damage, property loss, and psychological impacts. Therefore, based on the article above, disasters are divided into 2 (two) natural disasters and non-natural disasters.

Article 1.2 of Acts Number 24 Year 2007 states that natural disasters are disasters caused by events or a series of events caused by nature, among others, earthquakes, tsunamis, volcanoes, floods, drought, hurricanes, etc, and landslides. Article 1.3 of Acts Number 24 Year 2007 states that non-natural disasters are disasters caused by non-natural events or series of events, including technological failure, modernization failure, epidemics, and disease outbreaks. The government's determination informs that Covid-19 has hit and impacted Indonesia. Covid-19 is a non-natural disaster whose spread is so fast and widespread 
throughout the world that Covid-19 has been declared a pandemic.

With the vast potential for corruption during the Covid-19 period, the prosecution can still be criminal and civil. Bearing in mind that in Presidential Decree Number 12 Year 2020 concerning the Determination of Non-Natural Disasters, the spread of Covid-19 is designated as a national disaster. National disaster, in this case, refers to Article 2.3 of the Anti-Corruption Act, which states that "In the case of a criminal act of corruption as referred to in paragraph (1) is committed under certain circumstances, the death penalty is imposed." Through the Presidential Decree, which stipulates Covid-19 as a non-natural national disaster, this Covid-19 cannot be categorized as "in certain circumstances" where the perpetrator of a criminal act of corruption cannot be threatened with death if he commits corruption in any related policy.

\section{CONCLUSION}

Article 27.1 of Acts Number 2 Year 2020 does not create legal certainty because there is no detailed definition and explanation of the "economic costs," which may lead to misinterpretation in implementation. Therefore, to create legal certainty, it is necessary to implement regulation that explains what economic costs are meant by Acts Number 2 Year 2020, which provides further explanation of economic costs and state losses.

Article 27.2. Acts Number 2 Year 2020 aims to provide legal protection for state officials who want to make policies in handling Covid-19 but are hindered by the threat of criminal acts of corruption. Even though there is legal protection for the actions or policies of the government in the context of handling the Covid-19 virus outbreak, it should be noted that each of these actions and policies must be based on good faith.

\section{REFERENCES}

Act Number 01 Year 2004 About State Treasury

Act Number 15 Year 2006 About Financial Audit Board of the Republic of Indonesia

Adji, Indriyanto Seno. 2009. Korupsi dan Penegakan Hukum. Jakarta: Diadit Media.

Aminanto, Kif. 2017. Politik Hukum Pidana Disparitas Putusan Hakim dalam Tindak Pidana Korupsi. Jember: Jember Katamedia.

Anderson, James, Joel Hellman, Geraint Paul Jones, Bill Moore, Helga W Muller, Sanjay Pradhan, Randi Susan Ryterman, and M. Helen Sutch. 2000. Anticorruption in Transition: A Contribution to the Policy Debate. Washington DC: World Bank.
Bayley, J. Edward. 2009. "A Doctrine of Good Faith in New Zealand Contractual Relationships" Thesis in University of Catenbury.

Cabinet Secretariat Public Relation. 2020. "Realisasi Anggaran Pemulihan Ekonomi Nasional Capai Rp383,0" triliun", available at: https://setkab.go.id/realisasi-anggaranpemulihan-ekonomi-nasional-capai-rp38301-triliun/ (accessed 17 December 2020)

Chazawi, Adami. 2017. Hukum Pidana Korupsi di Indonesia. Jakarta: Rajawali Pers.

CNN Indonesia. 2020. "Virus Corona Masuk Indonesia, Netizen Serukan Jangan Panik", available at: https://www.cnnindonesia.com/teknologi/20200303141434192-480096/virus-corona-masuk-indonesia-netizen-serukanjangan-panik/ (accessed 27 July 2020)

Edward UP Nainggolan. 2020. "Strategi Kebijakan Pemulihan Ekonomi Nasional (PEN)", available at: https://www.djkn. kemenkeu.go.id/artikel/baca/13287/Strategi-KebijakanPemulihan-Ekonomi-Nasional.html/ (accessed 17 December 2020)

Indonesia Corruption Watch. 2020. "Tren Penindakan Kasus Korupsi 2019", available at: https://antikorupsi.org/id/article/trenpenindakan-kasus-korupsi-2019/ (accessed 30 July 2020)

Khairandy, Ridwan. 2004. Itikad Baik Dalam Kebebasan Berkontrak. Jakarta: Pascasarjana Indonesia University.

Kpundeh, Sahr John. 2008. "Limiting Administrative Corruption in Sierra Leone". Journal Modern African Vol.32: 145.

Marbun, S. F. 2001. Dimensi-Dimensi Pemikiran Hukum Administrasi Negara. Yogyakarta: UII Press.

Minister of Finance of the Republic of Indonesia Number 110/PMK.03/2020

Ministry of Finance. 2020. "Ini 5 Strategi Pembiayaan APBN 2020 di Masa Pandemi Covid-19". available at: https://www.kemenkeu.go.id/publikasi/berita/ini-5-strategipembiayaan-apbn-2020-di-masa-pandemi-covid-19/ (accessed 17 December 2020).

Ministry of Manpower. 2020. "Tightening of Work Pass Requirements". available at: https://www.mom.gov.sg/ newsroom/press-releases/2020/0827-tightening-of-workpass-requirements/ (accessed 19 January 2021).

Minister of Finance. 2020. "Press Conference APN KITA by Minister of Finance", available at: https://www.youtube.com/watch? $\mathrm{v}=\mathrm{eMaaygHD} 7 \times \mathrm{M}$ (accessed 20 Januari 2021).

Reniati. 2019. "The Effect of Covid-19 on The Economy of Bangka Belitung and The Performance of MSME and Its Impact On Competitive Strategies in The New Normal Era. Annals of Management and Organization Research" Journal of Faculty of Economy Bangka Belitung University 1(1): 51. https://doi.org/10.35912/amor.v1i1.289

Riana, Rati, Muhammad Junaidi. 2018. "Konstitusionalisasi Pembentukan Peraturan Perundang-Undangan Melalui Penggunaan Bahasa Indonesia Baku" Legislation Journal Indonesia Faculty of Law Semarang University 15(4): 276.

Soesilo, R. 1995. Kitab Undang-Undang Hukum Pidana. Bogor: Politea.

Solechan. 2019. "Asas-Asas Umum Pemerintahan yang Baik dalam Pelayanan Publik" Administrative Law \& Governance Journal Faculty of Law Diponegoro University 2 (3): 547. https://doi.org/10.14710/alj.v2i3.541-557

Sudarto. 2009. Hukum Pidana I. Semarang: Sudarto Foundation.

Sumadji, Harryono. 2011. "Analisis Biaya Untuk Pengambilan Keputusan Bisnis Balance Economics". Business, Management and Accounting Journal 08(14): 12.

Thaib, Dahlan. 2000. Kedaulatan Rakyat, Negara Hukum dan Konstitusi. Yogyakarta: Liberty.

The Indonesia Regional Science Association (IRSA). 2020. "Hasil Survei Ekonom terkait Kebijakan Saat Krisis Covid-19" 
available at: http://irsa.or.id/wp-content/uploads/2020/04/ Survei_Covid-19.pdf/ (accessed 30 July 2020)

Thomsen, Frej Klem. 2003 "Concept, Principle, and Norm-Equality before the Law Reconsidered" Legal Theory Journal Cambridge University 24(02): 124.

Wallerstein, Immanuel. 2003 "Citizens All? Citizens Some! The Making of the Citizen", Comparative Studies in Society and
History Journal New Haven Yale University 45(04): 658. https://doi.org/10.1017/S0010417503000318

Yuntho, Emerson. 2014. Penerapan Unsur Merugikan Keuangan Negara dalam Delik Tindak Pidana Korupsi. Indonesia Corruption Watch.

Received on 25-08-2021

Accepted on 10-10-2021

Published on 28-10-2021

https://doi.org/10.6000/1929-4409.2021.10.162

(C) 2021 Ginting and Gabriella; Licensee Lifescience Global.

This is an open access article licensed under the terms of the Creative Commons Attribution License (http://creativecommons.org/licenses/by/4.0/) which permits unrestricted use, distribution and reproduction in any medium, provided the work is properly cited. 